\title{
EVALUASI PENGELOLAAN KEUANGAN DESA DI DESA TIMBUSENG KECAMATAN PATTALLASSANG KABUPATEN GOWA \\ Muttiarni $^{1}$, Amiruddin ${ }^{2}$, Riska Amelia ${ }^{3}$ \\ Universitas Muhammadiyah Makassar
}

e-ISSN 2686-0058
p-ISSN 2715-7695
Informasi Artikel
Tanggal masuk
30 Mei 2020
Tanggal revisi
07 Juni 2020
Tanggal diterima
30 Juli 2020
Kata Kunci:
Evaluation ${ }^{1}$
Financial Management ${ }^{2}$
Transparent
${ }^{2}$
Accountable
Partisipatory
Orderly and budget
discipline 6

\begin{abstract}
This research aimed to evaluate governmental financial management at Desa Timbuseng Kecamatan Pattallassang Kabupaten Gowa based on transparent, accountable, participative, order and dicipline budgetting principles. This research was a descriptive approach. The analysis technique was qualitative analysis. The data collection techniques were interview and documentation. Data collection from interview and documentation compared with indicators compatible Pemendagri No.20 of 2018. The result indicated that the financial management on Desa Timbuseng is compatible with Pemendagri No.20 of 2018 is transparent, accountable, participative, order and discipline budgetting principle with the fullfillment of all indicators and govermental financial management very effective and enough and beneficial for the society
\end{abstract}

\begin{abstract}
Abstrak: Penelitian ini bertujuan untuk mengevaluasi bagaimana pengelolaan keuangan desa di Desa Timbuseng Kecamatan Pattallassang Kabupaten Gowa berdasarkan asas transparan, akuntabel, partisipatif, tertib dan disiplin anggaran. Jenis penelitian yang digunakan dalam penelitian ini adalah pendekatan deskriftif. Teknik analisis data yang digunakan adalah analisis kualitatif. Teknik pengumpulan data yang digunakan terdiri dari wawancara dan dokumentasi. Dari hasil wawancara dan dokumentasi tersebut, dibandingkan dengan menggunakan indikator-indikator sesuai dengan Pemendagri No. 20 Tahun 2018. Hasil penelitian menunjukkan bahwa pengelolaan keuangan pemerintah Desa Timbuseng telah sesuai dengan Pemendagri No. 20 Tahun 2018 yaitu transparan, akuntabel, partisipatif, tertib dan disiplin anggaran dengan terpenuhinya semua indikator serta pengelolaan keuangan desa yang sangat efektif sehingga cukup dan bermanfaat bagi masyarakat.
\end{abstract}

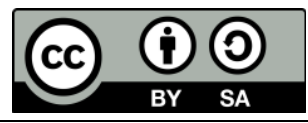

\section{PENDAHULUAN}

\section{Latar Belakang}

Susunan pemerintahan terkecil dalam suatu negara adalah desa. Pemendagri No. 20 Tahun 2018 menyatakan, Desa adalah kesatuan masyarakat hukum yang memiliki batas-batas wilayah yang berwenang untuk mengatur dan mengurus urusan pemerintah, kepentingan masyarakat setempat berdasarkan prakarsa masyarakat, hak asal usul, dan/atau hak tradisional yang diakui dan dihormati dalam sistem pemerintahan Negara Kesatuan Republik Indonesia.

Desa sebagai ruang lingkup terkecil dari struktur pemerintahan menjadi salah satu fokus utama pemerintah dalam pembangunan negara. Dalam perkembangannya, desa dituntut untuk melakukan reaktualisasi guna mencapai masyarakat sejahtera dan bebas dari kemiskinan. Hal tersebut dapat dicapai salah satunya dengan adanya pengelolaan keuangan yang baik. Sesuai 
Peraturan Menteri Dalam Negeri No. 20 Tahun 2018 yang menyebutkan bahwa "Keuangan desa dikelola berdasarkan asas transparan, akuntabel, partisipatif serta dilakukan dengan tertib dan disiplin anggaran. Dengan adanya peraturan tersebut pemerintah desa mempunyai landasan dalam mengelola keuangan desa dan diharapkan pemerintah desa mampu mengelola keuangan desa dengan baik.

Sejak digulirkannya dana desa pada tahun 2015 dengan jumlah Rp 186 Triliun, dari data Kompas.com (dimuat 21 November 2018) yang dikemukakan oleh Peneliti Indonesian Corruption Watch (ICW) tercatat sedikitnya 181 kasus korupsi dana desa dengan kerugian mencapai Rp 40,6 Miliar yang mengalami peningkatan setiap tahunnya (diakses 17 Maret 2019), sedangkan dari data peneliti Anti Corruption Committe (ACC) Sulawesi yang dimuat dalam Rakyatku.com (9 Januari 2019) terdapat 11 (sebelas) Kabupaten di Sulawesi Selatan yang terlibat dalam kasus penyelewengan dana desa antara lain, Kabupaten Bone, Luwu Timur, Sidrap, Pangkep, Selayar, Takalar, Maros, Bulukumba, Soppeng, Luwu Utara dan Sinjai. (diakses 17 Maret 2019).

Guna menghindari terjadinya penyelewengan dalam pengelolaan keuangan desa, semua lapisan mulai dari aparat berwenang hingga masyarakat yang harus mengetahui konsep dasar akuntabilitas dan transparansi agar tidak adanya sikap apatis dalam proses pengelolaan keuangan desa. Pengelolaan keuangan desa yang diatur dalam Peraturan Menteri Dalam Negeri No. 20 Tahun 2018 yang merupakan keseluruhan kegiatan yang meliputi perencanaan, pelaksanaan, penatausahaan, pelaporan dan pertanggungjawaban keuangan desa.

Pemahaman tentang pengelolaan keuangan desa merupakan aspek penting dan mendasar yang harus dimiliki oleh perangkat pemerintah desa. Beberapa penelitian sebelumnya telah melakukan pengujian terhadap pengelolaan keuangan desa seperti Stefanus Dimasias Aditya (2018) menunjukkan bahwa pengelolaan keuangan pemerintah Desa Sambirejo Kecamatan Ngawen Kabupaten Kidul telah sesuai dengan asas transparan, akuntabel,partisipatif, tertib dan disiplin anggaran dengan terpenuhinya semua indikator yang ditetapkan. Penelitian yang sama dikemukakan dalam penelitian Ni Nyoman Alit dan Susi Handayani (2018) dengan objek berbeda.

Desa Timbuseng yang menjadi objek penelitian ini merupakan salah satu desa yang terletak di Kecamatan Pattallassang Kabupaten Gowa yang memiliki Dana Alokasi Desa pada tahun 2018 sebesar Rp 703.824.093,- sedangkan untuk tahun 2019 sebesar 744.211.594,dimana dana ini memerlukan pengelolaan keuangan yang baik sesuai dengan asas transparan, akuntabel, partisipatif serta dilakukan dengan tertib dan disiplin anggaran.

Berdasarkan beberapa penelitian terdahulu rata-rata pemerintah desa telah mengelola keuangannya dengan baik dan sesuai asas-asas pengelolaan keuangan desa. Oleh karena itu, penelitian ini mencoba melihat apakah keuangan desa Timbuseng telah dikelola sesuai dengan asas transparan, akuntabel, partisipatif, tertib dan disiplin anggaran. Maka peneliti tertarik untuk melakukan penelitian tentang "Evaluasi pengelolaan keuangan desa di Desa Timbuseng Kecamatan Pattallassang Kabupaten Gowa" Tujuan Penelitian

Untuk mengevaluasi bagaimana pengelolaan keuangan desa di Desa Timbuseng kecamatan Pattallassang Kabupaten Gowa telah sesuai dengan asas transparan, akuntabel, patisipatif serta dilakukan dengan tertib dan disiplin anggaran. 


\section{TINJAUAN PUSTAKA EVALUASI}

Evaluasi dalam pengelolaan keuangan desa diperlukan untuk memastikan bahwa keuangan desa dikelola berdasarkan tahapan-tahapannya tanpa adanya unsur penyelewengan.

Evaluasi adalah proses pengambilan keputusan melalui kegiatan membandingbandingkan hasil pengamatan terhadap suatu objek. (Soemalis yang dikutip oleh Aljannah.,2017) dan Evaluasi merupakan kegiatan pemberian nilai atas sesuatu fenomena didalamnya terkandung pertimbangan nilai. (Mustofadijaja yang dikutip oleh Fahrizal.,2018)

Menurut William N. Dunn yang dikutip oleh Somborarak (2014) kriteria evaluasi untuk mencapai sasaran sesuai tujuan yang telah ditentukan terdiri atas empat tipe yaitu :

1. Efektivitas, yaitu apakah hasil yang di inginkan telah tercapai;

2. Kecukupan, yaitu seberapa jauh hasil yang telah tercapai dapat memecahkan masalah;

3. Responsivitas, yaitu apakah hasil kebijakan memuaskan kebutuhan prefensi atau nilai-nilai kelompok-kelompok tertentu;

4. Ketepatan, yaitu apakah hasil yang dicapai bermanfaat

Menurut South N, Tinangon J dan Rondonuwu S (2016) Efektivitas dapat dinilai berdasarkan :

Efektivitas $=\underline{\text { Realisasi Penerimaan }} \times 100 \%$

Target

Adapun standar ukuran efektivitas sesuai acuan Litbag Depdagri yang dijabarkan oleh Yuniastri S dan Ratna A.K (2015) yaitu :

Tabel 2.1

Standar Efektivitas

\begin{tabular}{|l|l|}
\hline \multicolumn{1}{|c|}{ RasioEfektivitas } & \multicolumn{1}{c|}{ Tingkat Capaian } \\
\hline Dibawah 40 & Sangattidakefektif \\
\hline $40-59,99$ & Tidakefektif \\
\hline $60-79,99$ & Cukupefektif \\
\hline Diatas 80 & Sangatefektif \\
\hline
\end{tabular}

Sumber : Litbang Depdagri, 1991

\section{KEUANGAN DESA}

Menurut Pemendagri No.20 Tahun 2018, "Keuangan desa adalah semua hak dan kewajiban desa yang dapat dinilai dengan uang serta segala sesuatu berupa uang dan barang yang berhubungan dengan pelaksanaan hak dan kewajiban desa". Hak dan kewajiban yang dimaksud menimbulkan pendapatan, belanja, pembiayaan, dan pengelolaan keuangan desa.

Anggaran Pendapatan dan Belanja Desa (APBDesa) merupakan rencana keuangan tahunan pemerintah desa. APBDesa merupakan dokumen formal hasil kesepakatan antara pemerintah desa dan Badan Permusyawaratan Desa yang berisi tentang belanja yang ditetapkan untuk melaksanakan kegiatan pemerintah desa selama satu tahun dan sumber pendapatan yang diharapkan untuk menutup keperluan belanja tersebut dan pembiayaan yang diperlukan bila diperkirakan akan terjadi defisit atau surplus. Pengelolan APBDesa didasarkan pada prinsip partsipatif, transparansi, akuntabilitas serta dilakukan dengan tertib dan disiplin anggaran, 
sehingga mendorong dan memastikan bahwa pemerintahan desa akan dikelola dengan baik. Adapun komponen anggaran tersebut terdiri dari :

1. Pendapatan desa

2. Belanja Desa

3. Pembiayaan Desa

\section{PENGELOLAAN KEUANGAN DESA}

Pengertian Pengelolaan Keuangan Desa

Menurut Pemendagri No. 20 Tahun 2018 dijelaskan bahwa "Pengelolaan Keuangan Desa adalah seluruh kegiatan yang meliputi perencanaan, pelaksanaan, penatausahaan, pelaporan dan pertanggungjawaban keuangan desa".

\section{Asas Pengelolaan keuangan Desa}

Menurut Pemendagri No. 20 Tahun 2018 Pasal 2 menyebutkan bahwa "Keuangan desa dikelola berdasarkan asas transparan, akuntabel, partisipatif serta dilakukan dengan tertib dan disiplin anggaran". Dengan adanya asas-asas tersebut diharapkan pemerintah desa dapat transparan dalam mengelola keuangan desa, serta akuntabel dalam menyusun laporan keuangan serta tertib dalam penggunaan anggaran.

\section{a. Transparansi}

Transparansi berarti pemerintah desa bersifat terbuka dalam mengelola keuangan desa, karena keuangan itu sendiri adalah milik rakyat atau barang publik yang harus diketahui oleh masyarakat.Indikator transparansi yang dikemukakan dalam Pemendagri No. 20 Tahun 2018 yakni:

1. Kepala Desa menyampaikan informasi mengenai APBDesa kepada masyarakat melalui media informasi

2. Informasi memuat APBDesa, pelaksanaan kegiatan anggaran, alamat pengaduan.

b. Akuntabilitas

Akuntabilitas merupakan perwujudan kewajiban untuk mempertanggungjawabkan pengelolaan dan pengendalian sumber daya dan pelaksanaan kebijakan yang dipercayakan dalam rangka pencapaian tujuan yang telah ditetapkan.Adapun indikator akuntabilitas dalam Pemendagri No. 20 Tahun 2018 yang dilakukan untuk pengukuran ini yakni

1. Tahap perencanaan

a. Perencanaan pengelolaan keuangan desa dianggarkan dalam APBDesa

b. Penyusunan rancangan APB Desa berdasarkan RKP Desa tahun berkenaan.

2. Tahap pelaksanaan

a. Pengelolaan keuangan desa dilaksanakan melalui rekening kas desa.

b. Kaur dan kasi pelaksana kegiatan anggaran menyusun Dokumen Pelaksana Anggaran (DPA)

c. Kaur keuangan mencatat pengeluaran anggaran kedalam buku kas umum dan buku kas panjar

3. Tahap penatausahaan

a. Penatausahaan dilakukan oleh kaur keuangan sebagai pelaksana fungsi kebendaharaan..

b. Penatausahaan dilakukan dengan mencatat setiap penerimaan dan pengeluaran dalam buku kas umum. 
4. Tahap pelaporan

a. Kepala desa menyampaikan laporan pelaksanaan realisasi APB Desa semester pertama kepada Bupati/Walikota melalui camat

b. Laporan semester pertama berupa laporan pelaksana APB Desa dan laporan realisasi kegiatan

5. Tahap pertanggungjawaban

a. Kepala desa menyampaikan laporan pertanggungjawaban realisasi APB Desa kepada Bupati/Walikota setiap tahun anggaran.

b. Laporan pertanggungjawaban terdiri atas laporan keuangan, laporan realisasi kegiatan dan daftar program sektoral, program daerah dan program lainnya yang masuk ke desa.

c. Partisipatif

Partisipatif adalah penyelenggaraan pemerintah desa yang mengikutsertakan kelembagaan desa dan unsur masyarakat desa. Menurut Fadil (2017) partisipasi adalah persoalan relasi kekuasaan, atau relasi ekonomi politik yang dianjurkan oleh demokrasi.Indikator partisipatif dalam Pemendagri No. 20 tahun 2018 yakni :

1. Rancangan Peraturan Desa tentang APBDesa yang disampaikan kepala desa kepada Badan Permusyawaratan Desa (BPD) untuk dibahas dan di sepakati bersama dalam musyawarah.

2. Masyarakat ikutserta dalam kegiatan pemerintahan desa.

d. Tertib dan disiplin anggaran

Tertib dan disiplin anggaran yaitu pengelolaan keuangan desa harus mengacu pada aturan atau pedoman yang melandasinya. Menurut Pemendagri No. 20 Tahun 2018, pengelolaan keuangan desa dikelola dalam masa satu tahun anggaran yakni tanggal 1 Januari sampai tanggal 31 Desember. Adapun indikator tertib dan disiplin anggaran yang tertuang dalam Pemendagri No. 20 Tahun 2018 yakni :

1. Pengelolaan keuangan dikelola dalam tahun anggaran tanggal 1 Januari sampai 31 Desember

2. Pelaksana anggaran dilakukan oleh kaur dan kasi

3. Tata cara penggunaan anggaran diatur dalam peraturan Bupati/Walikota mengenai pengelolan keuangan desa.

\section{Tahapan Pengelolaan keuangan desa}

a. Perencanaan

Perencanaan pengelolaan keuangan desa merupakan perencanaan penerimaan dan pengeluaran pemerintahan desa pada tahun anggaran berkenaan dengan yang dianggarkan dalam APB Desa.

b. Pelaksanaan

Pelaksanaan pengelolaan keuangan desa merupakan penerimaan dan pengeluaran desa yang dilaksanakan melalui rekening kas desa.

c. Penatausahaan

Penatausahaan dilakukan oleh kaur keuangan sebagai pelaksana fungsi kebendaharaan. Kaur keuangan wajib melakukan pencatatan setiap penerimaan dan pengeluaran dalam buku kas umum serta melakukan tutup buku setiap akhir bulan.

d. Pelaporan 
Kepala desa menyampaikan laporan pelaksanaan APB Desa kepada Bupati/Walikota melalui camat. Laporan yang dimaksud terdiri dari :

a) Laporan pelaksanaan APB Desa

b) Laporan realisasi anggaran

e. Pertanggungjawaban

Kepala desa menyampaikan laporan pertanggungjawaban realisasi APB Desa kepada Bupati/Walikota melalui camat setiap akhir tahun anggaran dan paling lambat 3 (tiga) bulan setelah akhir tahun anggaran.

\section{METODE PENELITIAN}

\section{Jenis Penelitian}

Jenis penelitian ini yang digunakan dalam penelitian ini adalah jenis penelitian dengan menggunakan pendekatan kualitatif. Menurut Sugiyono (2014) metode penelitian kualitatif adalah metode penelitian yang digunakan untuk meneliti pada kondisi objek yang alamiah dimana peneliti adalah sebagai instrumen kunci, teknik pengumpulan data digunakan secara trianggulasi (gabungan), analisis data bersifat induktif, dan hasil penelitian kualitatif lebih menekankan makna dari generalisasi.

\section{Fokus Penelitian}

Penelitian ini berusaha mendeskripsikan bagaimana para pelaku memahami sistem pengelolaan keuangan desa melalui data-data yang dikumpulkan yang kemudian dijelaskan dengan kata-kata dalam penelitian ini.

\section{Lokasi dan Waktu Penelitian}

Lokasi penelitian Evaluasi pengelolaan keuangan desa ini berada pada Desa Timbuseng Kecamatan Pattallassang Kabupaten Gowa. Penelitian ini dilakukan dalam jangka waktu pada bulan Mei sampai Juni ditahun 2019.

\section{Populasi dan Sampel}

Fokus dalam penelitian ini adalah beberapa informasi yang dipercaya dapat memberikan informasi yang akurat. Sesuai ketentuan Pemendagri No.20 Tahun 2018 subjek tersebut meliputi :

1. Kepala desa

2. Pelaksana Pengelolaan Keuangan Desa yang selanjutnya disingkat PPKD adalah perangkat desa yang melaksanakan pengelolaan keuangan desa. PPKD terdiri atas :

a. Sekretaris desa

b. Kaur dan Kasi

c. Kaur keuangan

d. Masyarakat desa

Adapun sampel dalam penelitian ini adalah Kepala desa dan Kaur Keuangan pada Desa Timbuseng.

\section{Sumber Data}

Data Primer yaitu data yang diperoleh secara langsung dari objek penelitian dalam hal ini adalah Kepala desa dan Kaur keuangan desa Timbuseng.

Data sekunder yaitu data yang diperoleh dari sumber yang sudah ada. 


\section{Pengumpulan Data}

1. Dokumentasi adalah catatan peristiwa yang telah berlalu baik berupa tulisan seperti Laporan APBDesa atau gambar seperti Baliho yang digunakan di desa Timbuseng.

2. Wawancara adalah percakapan dengan maksud tertentu, yang dilakukan oleh dua pihak yaitu pewawancara (peneliti) yang mengajukan pertanyaan dan yang diwawancarai (Kepala desa dan Kaur Keuangan) yang memberikan jawaban atas pertanyaan yang telah diberikan.

\section{Teknik Analisis Data}

Miles, Huberman dan Saldana dalam Wahyu (2018) mengatakan bahwa ada tiga jalur analisis data kualitatif yakni Reduksi data (data reduction), penyajian data (data display) dan penarikan kesimpulan (conclusion drawing).

\section{HASIL DAN PEMBAHASAN}

Analisis Data

Tingkat Efektivitas Anggaran Pendapatan dan Belanja Desa Timbuseng 2018

\begin{tabular}{|l|r|r|c|}
\hline \multicolumn{1}{|c|}{ Keterangan } & $\begin{array}{r}\text { RealisasiPenerimaa } \\
\mathrm{n}(\mathrm{Rp})\end{array}$ & Target (Rp) & $\begin{array}{c}\text { Capaia } \\
\mathrm{n}(\%)\end{array}$ \\
\hline Pendapatan & $389.674 .631,-$ & $389.684 .066,-$ & 99,99 \\
\hline PendapatanAsliDesa & $1.888 .627 .066,-$ & $\begin{array}{r}1.913 .706 .912, \\
-\end{array}$ & 98,68 \\
\hline Pendapatan Transfer & $50.000 .000,-$ & $50.000 .000,-$ & 100 \\
\hline Lain-lain Pendapatandesa yang sah & $553.334 .200,-$ & $569.795 .769,-$ & 97,11 \\
\hline Belanja & $1.427 .085 .036,-$ & 1.451 .085 .044$, & 98,34 \\
\hline $\begin{array}{l}\text { BidangPenyelenggaraPemerintahDe } \\
\text { sa }\end{array}$ & $138.542 .000,-$ & $138.704 .884,-$ & 99,88 \\
\hline $\begin{array}{l}\text { BidangPelaksana } \\
\text { Desa }\end{array}$ & $198.057 .300,-$ & $198.057 .300,-$ & 100 \\
\hline Bidang Pembina Kemasyarakatan &
\end{tabular}

Sumber data : Laporan Realisasi Anggaran Pendapatan dan Belanja Desa Timbuseng 2018

Hasil perhitungan tersebut diatas, efektivitas pengelolaan keuangan Desa Timbuseng tahun 2018 dari masing-masing item pendapatan dan belanja menunjukkan angka diatas 80 persen yang artinya sangat efektif. Hal tersebut didukung dengan hasil evaluasi peneliti terhadap pengelolaan keuangan Desa Timbuseng dan dari hasil wawancara yang dilakukan dapat penulis simpulkan bahwa pengelolaan keuangan Desa Timbuseng dari perencanaan sampai pertanggungjawabannya telah sesuai dengan Pemendagri No. 20 Tahun 2018 dimana masyarakat dapat memperoleh informasi anggaran melalui media komunikasi grup sebagai bentuk transparansi pemerintah desa serta berdasarkan temuan peneliti terdapat informasi anggaran yang dapat di akses masyarakat melalui baliho yang terdapat di depan aula Desa Timbuseng. Sedangkan dari segi akuntabilitas, pengelolaan keuangan Desa Timbuseng telah mencatat seluruh penerimaan dan pengeluarannya dalam Buku Kas Umum, Buku Pembantu 
Kas Tunai dan Buku Pembantu Pajak serta diterbitkannya Laporan realisasi APBDesa dan Laporan kegiatan setiap akhir tahun anggaran sebagai perwujudan dari pertanggungjawaban pemerintah desa terhadap pengelolaan dan pengendalian keuangan Desa Timbuseng.

Dari segi partisipatif, diadakannya musyawarah yang dilakukan untuk perancangan peraturan desa tentang APBDesa yang mengikutsertakan BPD, Tokoh masyarakat, dan lembaga-lembaga yang terdapat di Desa Timbuseng. Sedangkan dari segi tertib dan disiplin anggaran Desa Timbuseng melakukan penganggaran sesuai aturan yakni 1 Januari sampai 31 Desember tahun berkenaan yang tatacara penggunaan anggarannya diatur dalam peraturan Bupati. Adapun pengelolaan keuangan Desa Timbuseng menunjukkan rasio efektivitas diatas 80 persen yang artinya sangat efektif, hal tersebut didukung dari pengamatan penulis dengan adanya pembangunan aula desa yang digunakan untuk mengadakan pertemuan dan musyawarah desa dan kegiatan-kegiatan lainnya, didirikannya sekolah PAUD, perbaikan lorong-lorong serta pemukiman masyarakat kurang mampu sehingga hal tersebut memuaskan dan bermanfaat untuk masyarakat Desa Timbuseng.

\section{PENUTUP}

\section{Kesimpulan}

Kesimpulan dari hasil penelitian ini berdasarkan Pemendagri No. 20 Tahun 2018, Pemerintah Desa Timbuseng telah mengelola keuangan Desa Timbuseng sesuai asas transparan, akuntabel partisipatif, tertib dan disiplin anggaran dengan tingkat efektivitas yang sangat tinggi sehingga kebijakan-kebijakan yang ditetapkan mampu mencukupi dan memberikan manfaat bagi masyarakat Desa Timbuseng.

\section{Saran}

Penelitian ini hanya membahas bagaimana pengelolaan keuangan desa secara teknis berdasarkan Pemendagri No. 20 Tahun 2018 sesuai asas transparan, Akuntabel , Partisipatif, tertib dan Disiplin anggaran. Sehingga saran untuk peneliti selanjutnya agar membahas tentang komponen pengelolaan keuangan secara detail dan untuk pemerintah Desa Timbuseng semakin meningkatkan pengelolaan keuangan desanya untuk mensejahterakan masyarakatnya.

\section{DAFTAR PUSTAKA}

Aditya, S.D. 2018. Evaluasi Pengelolaan Keuangan Desa berdasarkan Asas Transparan, Akuntabel, Partisipatif, Tertib dan di Siplin Anggaran (Studi Kasus Desa Sambirejo Kecamatan Ngawen Kabupaten Gunung Kidull. Universitas Sanata Dharma.Yogyakarta.

Al Jannah, S. 2017. Evaluasi ADD dalam menunjang pembangunan desa di Kecamatan Tambusai Utara Kabupaten rokan Hulu (Studi Kasus : Desa Tambusai Utara tahun 2013-2014). JOM Fekom. Vol.4.

Andrianto, Nico. 2007. Transparansi dan Akuntabilitas Publik e-Goverment. Malang : Bayumedia publishing.

Anonim. 2018. Rencana Pembangunan Jangka Menengah Desa Timbuseng.

Arfah, J dan Musin,Y. 2017. Evaluasi pengelolaan Dana Alokasi Desa (DAD) dalam percepattan pembangunan desa di Kabupaten Konawe. 
Badan Pengawas Keuangan dan Pembangunan. 2015. Juklak Bimkon Pengelolaan Keuangan desa. Jakarta.

Damayanti, W. 2018. Transparansi dan Akuntabilitas Pemerintah Desa dalam Pengelolaan Alokasi Dana Desa (Studi Kasus : Desa Tegiri dan Desa Sumberaagung Kecamatan Batuwarno Kabupaten Wonogiri). Universitas Muhammadiyah Surakarta.

Fahrizal, M.G. 2018. Evaluasi implementasi pengelolaan keuangan desa di desa Kedungmaling dan desa Kumitir Kabupaten Mojokerto berdasarkan Pemendagri No.113 Tahun 2014. Universitas Airlangga.

https://www.google.com/amp/news.rakyatku.com/amp/134739

https://nasional.kompas.com/read/2018/11/21/19000481/icw-ada-181-kasuskorupsi-dana-desa-rugikan-negara-rp-406-miliar

Kirowati, D et.al., 2017. Penerapan azas pengelolaan keuangan desa (Studi kasus Desa Temboro Kecamatan Karas Kabupaten Magetan). Madiun.

Kisnawati, B et.al., 2018. Transparansi dan akuntabilitas pengelolaan keuangan Alokasi Dana Desa (ADD) di Kecamatan Moyo Hilir Kabupaten Sumbawa Besar. Sekolah Tinggi Ilmu Ekonomi AMM Mataram.

Lengkong, V.P,K dan Tasik H.H,D. 2018. Evaluasi pengelolaan dana desa dengan instrumen dimensi pengukuran pengelolaan dana desa (DP2D2) berdasarkan UU No. 6 Tahun 2014.

Miftahuddin. 2018. Akuntabilitas dan Transparansi Pemerintah Desa terhadap Pengelolaan Dana Desa (Studi Kasus: Desa Panggungharjo Kecamatan Sewon Kabupaten Bantul). Universitas Islam Yogyakarta.

Mulyani Indrawati, S. 2017. Buku Pintar Dana Desa. Jakarta: Kementrian Keuangan RI

Munirah. 2018. Evaluasi pengelolaan dana desa di desa Lubuk Kecamatan Kundur Kabupaten Karimun Tahun 2017. Universitas Maritim Raja Ali Haji.

Pemendagri No. 113 Tahun2014. Tentang Pedoman Pengelolaan Keuangan Desa.

Pemendagri No. 1 Tahun 2017 . tentang Penataan Desa.

Pemendagri No. 20 Tahun 2018. Tentang Pengelolan Keuangan Desa

Shafratunnisa, F. 2015. Penerapan Prinsip Transparansi dan Akuntabilitas dalam Pengelolaan Keuangan kepada Stakeholders di SD Islam Binakheir. Jakarta : Universitas Islam Negeri Syarif Hidayatullah.

Somborak, A. 2014. Evaluasi Program Alokasi Dana Desa di Desa Loa Janan Kecamatan Loa Janan Kabupaten Kutai Kartanegara.

South, N, Tinangon J dan Rondonuwu S. 2016. Pengukuran efisiensi dan efektivitas pengelolaan keuangan daerah pada Dinas Pengelolaan Keuangan, pendapatan dan Aset (DPKPA) Kabupaten Minahasa Selatan. Jurnal EMBA Vol 4 No.4.

Sujarweni, V.W. 2015. Akuntansi Desa : Panduan Tata Kelola Keuangan Desa. Yogyakarta : Pustaka Baru Press.

Tanjung, A.H.2006. Akuntansi Pemerintah Daerah. Bandung: Alfabeta

Triani, N.N.A dan Handayani, S.2018. Praktik pengelolaan keuangan dana desa. Universitas Negeri Surabaya

Ulumuddin, A. 2018. Evaluasi Dana Desa di Desa Puser Kecamatan Tirtayasa Kabupaten Serang tahun 2016. Universitas Sultan Ageng Tirtayasa. Serang. 
Wahyu, 2018. Akuntabilitas dan Transparansi Pemerintah Desa dalam Pengelolaan Alokasi Dana Desa (ADD) di Desa Borong Pa'la'la Kecamatan Pattallassang Kabupaten Gowa. Universitas Muhammadiyah Makassar

Widiyanti, A. 2017. Akuntabilitas dan Transparansi Pengelolan Alokasi Dana Desa (Studi Kasus pada desa Sumberejo dan desa Kandung di Kecamatan Winongan Kabupaten Pasuruan). Universitas Islam Negeri Malang.

Wijaya, D. 2018. Akuntansi Desa. Yogyakarta: Gava Media Yuliansyah, Rusmianto. 2015. Akuntansi Desa. Jakarta : Salemba Empat.

Yunita S.N.L.A.K dan Wiyati R.K. 2015. Pengukuran tingkat efektivitas dan efisiensi sistem Eresearch STIKOM Bali. 